\title{
中国淮河と我が国の流出試験地の年水収支の比較 \\ Comparison of Yearly Water Balance between Huai He River in China and Experimental Basins in Japan
}

岸井徳雄 ${ }^{*}$. 葛葉泰久 ${ }^{* *}$. 曹 述互 ${ }^{* * *}$ by Tokuo KISHII, Yasuhisa KUZUHA and Shuhu CAO

\begin{abstract}
Japan and China are located in the Asian monsoon region and received its effects. But the hydrological characteristics of the region are not studied enough. The Hua $\mathrm{i}$ He river in China have determined as the representative basin of GAME-T project, sub project of GEWEX.

This paper shows the difference of yearly water balance between the Huai He river and our experimental basins, that is Urajiro river and Tsukuba experimental basins etc. Keywords:Huai He river, GAME-T, Water balance, Experimental basins
\end{abstract}

1.はじめに

我が国と中国は、アジアモンスーン地帯に位置し、その影響を大きくうける。しかしながら水文特性に関 する研究は、十分とは、言えずその解明が必要とされている。そこで我が国の水収支特性との違いを明らか にするための第一歩として、淮河と当研究所の試験地である浦白川流出試験地及び筑波研究学園流出試験地 々の観測結果を利用して年水収支を比較する。また、ここで対象とする中国の淮河は、GAME-Tの試験流域で ある。

流域に降雨があった時、どのように流出が生じるかを予測することは、水文学上、あるいは実用上として、 洪水、渴水対策上重要な課題である。このような課題の解明には当該流域での詳細な水文観測資料の解析に 依り、降雨一流出の関倸特に水収支を明らかにする必要がある。さらに、この関係は流域条件により異なる と考えられるので、複数の流域での比較が必要である。

当研究所では、中国水利部遙感技術応用中心と淮河を対象として共同研究を進めて扔り、また流域条件の

* 正会員 防災科学技術研究所 気圈 - 水圈地球科学技術研究部 気候変動影響評価研究室長

（３05 茨城県つくば市天王台3-1）

** 正会員 工博 防災科学技術研究所 気圈 - 水圈地球科学技術研究部 水循環研究室 研究員

（３05＼cjkstart茨城県つくば市天王台3-1）

*** 中国水利部遙感技術応用中心 所長

( ₹ 2905 Baiguang Road, Beijing, China) 
粠なる浦白川流出試験地及び筑波研究学園 流出試験地を管理し、詳細な水文観測資料 の蓄積を進めてきた。今まで、この資料を 用いて、それぞれの試験地における洪水時 の降雨流出の関倸について報告がなされて きた

本論文では、それぞれの試験地での水収 支の結果を相互比較して、流域条件等との 関連について考察する。

各試験地の流域条件については、水収支 に関連の深い事項について簡潔に記す。本 報告で対象とする流

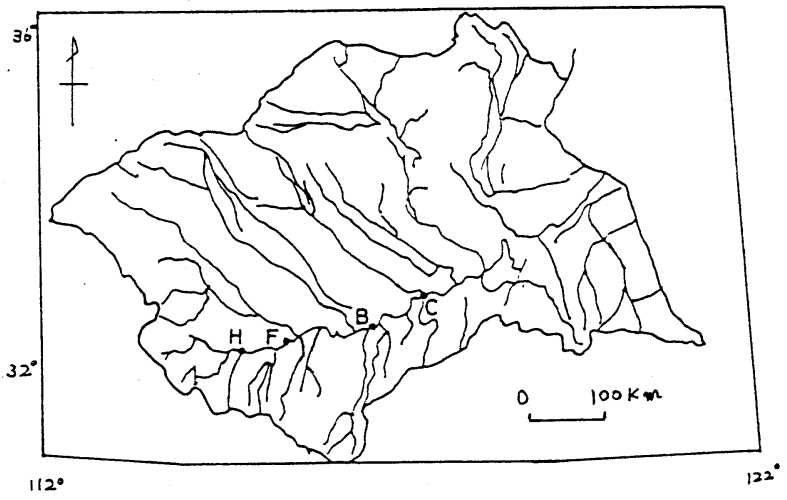
域は、中国の淮河、 わが国の当研究所の 管理する千葉県養老 川支川の浦白川流出 試験地（月崎流域抒 よび柿の木台流域) および茨城県つくば 市の筑波研究学園流 出試験地（上の室橋 流域㧍よび八千代橋 流域）である。観測 所の位置等について は図-1〜図-3に示す。

\section{2. 流域条件}

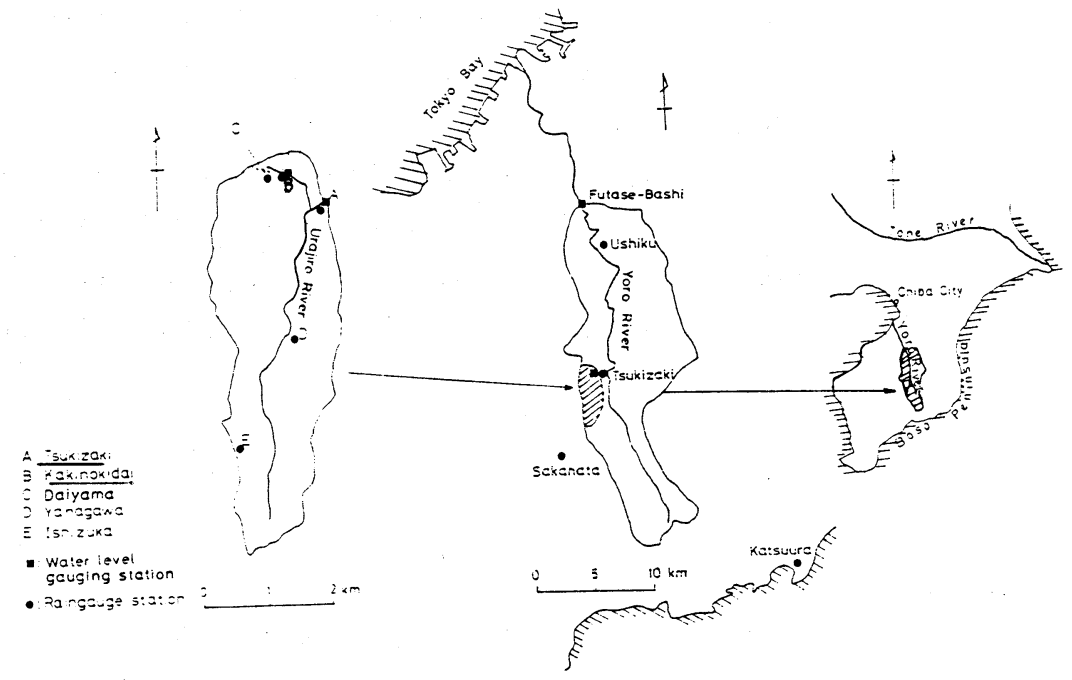

図-1 淮河流域と水文観測点 (C:蚌埠, B: 魯台子, F : 淮濱, H: 息具)

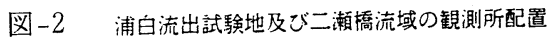

\section{1 地形}

流域面積は、准 河流域が、1.21 $12010^{5}$ $\mathrm{km}^{2}$ 柿の木台流域が $0.147 \mathrm{~km}^{2}$ で他流域に 比し、かなり小さく、 その他の流域は、月 崎流域で $9.04 \mathrm{~km}^{2}$ 、 上の室橋流域 12.46 $\mathrm{km}^{2}$ 、、八千代橋流域 $14.86 \mathrm{~km}$ “であり、い づれも $10 \mathrm{k} \mathrm{m}^{2}$ 前 後である。

流路勾配は、淮
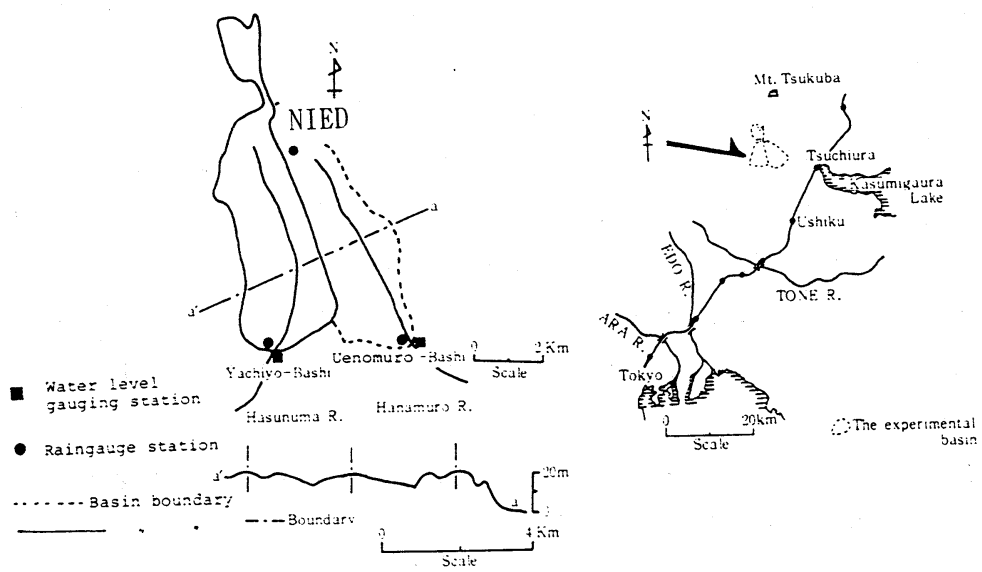

河流域は、支川で1： 


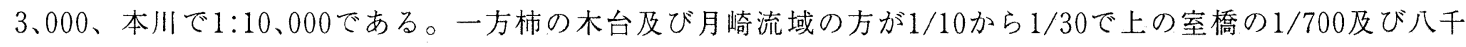
代橋流域の $1 / 500$ より 1 オーダ程度大きく、それぞれ山地河川と平地河川の特徵を示している。

\section{2 土地利用}

淮河流域では流域のほとんどが畑・水田として利用されており、林地は、ほとんどなく、西部抒よび南 西部の流域界付近の山地にあるのみである。

浦白川流出試験地の 2 流域では、林地の面積率は大きく、一方、筑波研究学園流出試験地の 2 流域では、 小さく、人工改変の進んだ土地利用を示している。不浸透面積率は、淮河流域では数％程度で、浦白川 流出試験地の 2 流域では、0\%程度であり、筑波研究学園流出試験地では20\%前後の值で、上の室橋流域の 方が八千代橋流域より大きい。

ここで、不浸透面積とは、道路、建物、池及び川等の面積和である。

\section{3 水文観測方法}

降水量は、径 $200 \mathrm{~mm} の 円$ 筒形の転倒マス型雨量計で観測されたものである。流量は、柿の木台に扰いては、 量水堰の越流深から堰の越流公式を用いて求めた。その他の流域は、低水時・高水時の流量観測から求めた。

\section{4 面積雨量}

淮河流域では計 9 箇所の雨量観測所があり、それぞれの流量観測所の上流域にある雨量観測所の雨量の算 術平均を面積雨量とした。 浦白川流出試験地には、計 5 箇所の雨量観測地点がある（前揭図-2）。そこで 最下流端の月崎流域の面積雨量は、これら 5 箇所の降水量の算術平均とした。柿の木台流域に対しては、柿 の木台地点の降水量を用いた。筑波研究学園流出試験地には、計 3 箇所の雨量観測地点がある（前揭図-3）。

上の室橋流域の面積雨量としては、上の室橋と当研究所の降水量の算術平均とした。八千代橋流域に対し ては、八千代橋地点と当研究所との降水量の算術平均を用いた。

なお、各試験地共、冬季において降雪がある年があるが、量的には少く、日降水量で見る限りでは、融解 により降雨として計測されるので降水量は、降雨量と考えてよい。

\section{3. 水収支}

水収支に倸わる水文要素としては、

(1) 流域への水の流入する量として、降水（降雨拈よび降雪） R 及び用水量 I (2) 流域から流出する 量として、河川の流量 $\mathrm{Q}$ 、蒸発散量 $\mathrm{E}$ 、当該観測所を通過しないで流域外へ流出する量 $\mathrm{G} 、$ 抢よび水収支期 間内にQ、Eとならないで流域の浅い部分㧍よび土塞中等に保留される水分の増加量 $\Delta \mathrm{S}$ 品なり、これらは (1)式で関倸づけられる。

$$
\mathrm{R}+\mathrm{I}=\mathrm{Q}+\mathrm{E}+\mathrm{G}+\Delta \mathrm{S}
$$

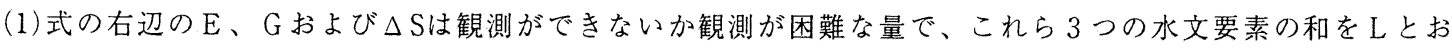
く。Lは、損失量とする。即ち、

$$
L=E+G+\Delta S
$$

その結果、(1)、(2)式より、

$$
\mathrm{R}+\mathrm{I}=\mathrm{Q}+\mathrm{L}
$$

となる。

また、降水量 $\mathrm{R} 及 ひ ゙$ 用水量 $\mathrm{I}$ と流量 $\mathrm{Q}$ の比を流出率と定義する。

$$
\mathrm{f}=\mathrm{Q} /(\mathrm{R}+\mathrm{I})
$$

\section{1 年水収支}

\section{1 .1 年水収支の意味}

年水収支の期間の境は河川の流量の変化が最も小さい時期が選ばれる。これは各年の年水収支を調べる場 合変動が少ないため、各年ほほ同一の水文サイクルとなるようにするためである。そこで水文年の境として 
冬期の低水流量が最小の時期とする方法もあるが、ここでは実用的に暦年、即ち 1 月から 12 月までを年水収 支の期間とする。この場合において、

蒸発散量 $\mathrm{E}$ および観測所を通過しない量 $\mathrm{G}$ は観測が困難であり、本試験地においてはこれらの量は観測さ れていない。そこで年間の $\mathrm{E}+\mathrm{G}$ 年損失量と考えそれぞれの水文量に添字 $\mathrm{y}$ をつ、年水収支式を、

$$
R y+I y=Q y+L y
$$

とする。

\section{4. 年水収支の解析結果}

各試験地の年降水量、年流出量㧍よび年損失量と共に、さらに養老人本川の二瀬橋流域（流域面積 $184.2 \mathrm{k}$ $\mathrm{m}^{2}$ : 図-2)に扔ける年降水量および年流出量を参考として加える。二瀬橋流域の年降水量は牛久、坂畑、勝 浦（いづれも気象庁のAMeDAS地点）扔よび浦白川流出試験地の年降水量の算術平均値とした。年流出量は千 葉県養老川開発事務所の資料による。二瀬橋流域の位置は前掲の図-2に示す。

\section{1 淮河流域の年水収支}

年降水量と年流出量の関係を示したのが 図-4である。この図から、推定すると年降 水量 $600 \mathrm{~mm}$ 程度で年流出量が $0 \mathrm{~mm}$ になること がわかる。年損失量は、年降水量 $700 \mathrm{~mm}$ $600 \mathrm{~mm}$ 、同じく $1,000 \mathrm{~mm}$ で $700 \mathrm{~mm}$ 、同じく $1,500 \mathrm{~mm}$ で $900 \mathrm{~mm}$ 程度というように年降水量 の増大と共に増加する傾向がみられる ${ }^{6)} 。$ また、年流出率は、図-4から分かる様に 0.2 〜 0.5程度であり、我が国の河川流域の年流 出率に比べて、かなり小さく、年損失量が 大きいことがわかる。

\section{2 浦白川流出試験地及び二瀬橋流域の年 水収支}

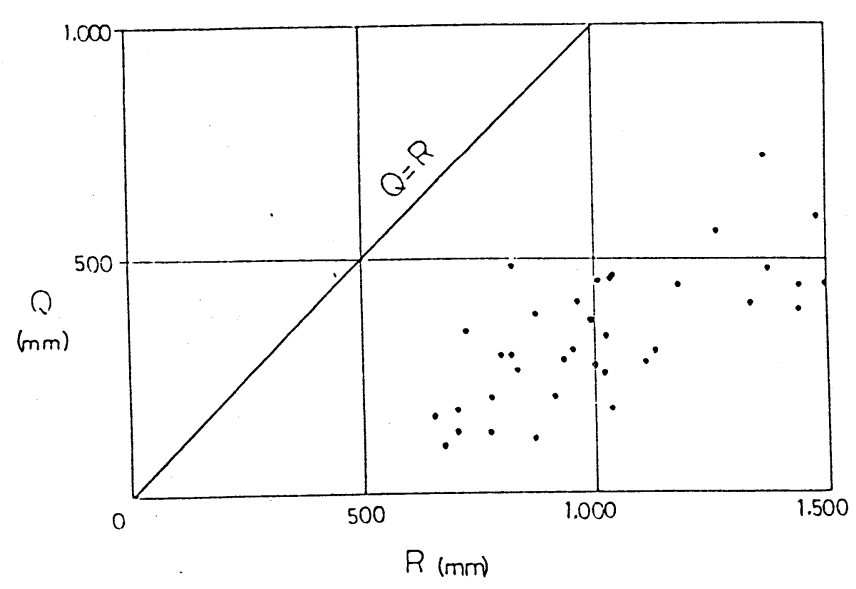

図-4 淮河流域の年降雨量一年流出量関係

図-5から、柿の木台及び月崎流域に㧍いて年降水量の増大と共に年損失量が大きくなる傾向がある。例え ば、年降水量が $1,000 \mathrm{~mm}$ 程度 で年損失量 $400 \sim 500 \mathrm{~mm}$ 、年降 水量 $1,500 \sim 1,600 \mathrm{~mm}$ で年損失 量700 900mm、年降水量 1,900 $\sim 2,200 \mathrm{~mm}$ で年損失量 400 $1,100 \mathrm{~mm}$ とっている。

（1）二瀬橋流域（図-5中× 印）では、年損失量は年降水 量の増加と共に増大している。

（2）年降水量が小さくなる と 3 流域とも年損失量は同程度 となるようである。

（3）二瀬橋流域（流域面積 は月崎流域の約 20 倍）では年損 失量が本試験地より小さい傾向

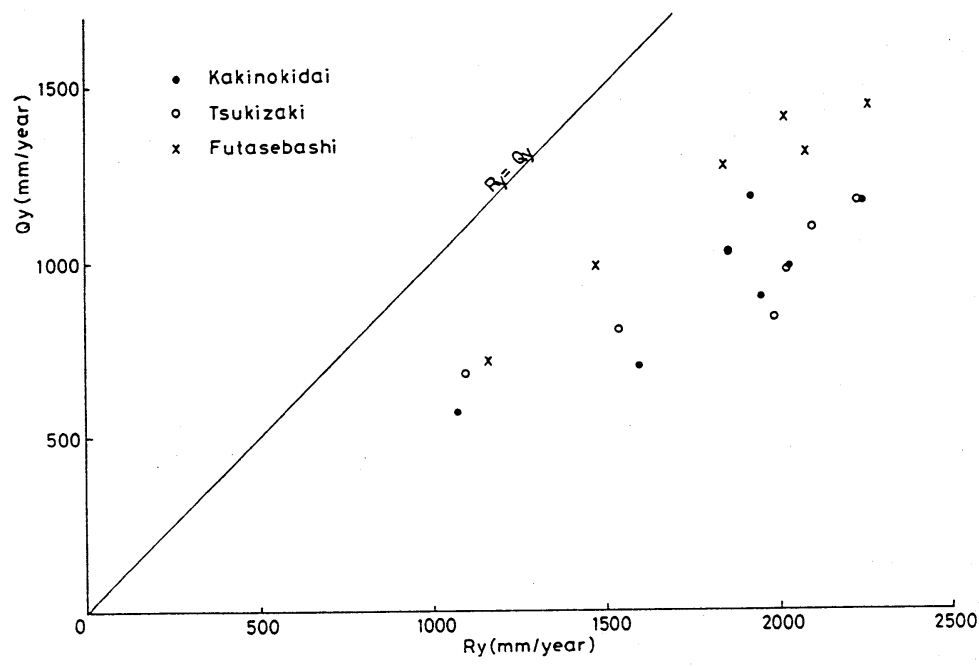

図-5

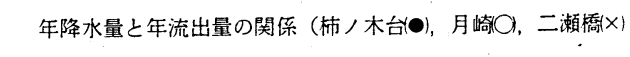


がある。

4.3 筑波研究学園流出試験 地の年水収支

筑波研究学園流出試験地の 上の室橋流域及び八千代橋流 域の年収支の結果を図-6に示 した。この図中○、○' は上の室橋流域を示し、メ、 ×'は八千代橋流域を示す。 両流域共、毎年 4 月 9 月の 期間に農業用水が流域外より 供給されており、この用水量 （I y) と年降·用水量 ( R y ) の和を横軸の値とした場合を ○'及びメ'で示した。この図から両流域共、年降・用水量（年降水量と流域内への用水供給量の和） 1,20 $0 \sim 1,500 \mathrm{~mm}$ で、年損失量7 $00 \sim 900 \mathrm{~mm}$ の範囲、年降・用水量 $1,500 \sim 2,000 \mathrm{~mm}$ で、年損失量 $600 \sim 1,200 \mathrm{~mm}$ の範囲 であり、年降・用水量の增大と共に年損失量が増大している。

\section{4 浦白川流出試験地および筑波研究学園流出試験地の比較}

このことを浦白川流出試験地の 2 流域と比較すると、年降・用水量 $1,000 \sim 1,500 \mathrm{~mm}$ では、筑波研究学園流 出試験地の 2 流域の年損失量がより大きい。また年降・用水量 $1,500 \mathrm{~mm}$ 以上となると両試験地の間の年損失量 は、ほほ同じとなる。年降・用水量が $1,500 \mathrm{~mm}$ 以下の場合の両試験地の間の年損失量の差異は、以下のように 考えられる。筑波研究学園流出試験地に扔いては、降雨は、時間をかけてゆっくりと河道に流出してくる。

この河道に流出してくる間に地中水が空気中へ蒸発散として失われる。この量は、河道に流出するまでの 時間の増大と共に増大するから、浦白川流出試験地に比べ、り多く蒸発散が生じ、損失量がより大きくな ると推定される。一方、年降・用水量が $1,500 \mathrm{~mm}$ 越える年に扔いては、両試験地共、1 年を通して、流域の 表層は、湿った状態の日が多く、同程度の可能蒸発散に近い損失量が生じているためではなかろうか。

\section{5 他流域との比較}

さらに当研究所の両試験地の年水収支と他流域の調查結果を比較すると以下の通りである。建設省の調 查によれば、関東地方の河川（利根川、神流川、荒川他、流域面積： $700 \mathrm{~km}^{2} \sim 2,200 \mathrm{~km}^{2}$ ）の年流出率は、 年降水量 $1,500 \mathrm{~mm} \sim 2,000 \mathrm{~mm}$ の年で平均 0.7 である゙”。年損失量で表わすと $450 \mathrm{~mm} \sim 600 \mathrm{~mm}$ である。農林水産省 林業試験場が管理する森林理水試験地の年水収支の結果によると年降水量が $1,700 \mathrm{~mm} \sim 1,800 \mathrm{~mm}$ 以上ある流域 では、年損失量は年降水量 $(1,700 \mathrm{~mm} \sim 3,800 \mathrm{~mm})$ に関係なく一定となることが報告されている。

これらの結果を相互比較すると、当研究所の両試験地の年損失量は、年降水量 $2,000 \mathrm{~mm}$ 程度の場合に 1,000 $\mathrm{mm}$ 程度である。一方建設省が調查した関東諸河川は流域面積が $700 \mathrm{~km}^{2} \sim 2,200 \mathrm{~km}^{2}$ と本試験地より大きく年 損失量が小さい傾向がある。このことと前述の結果即ち、当研究所の両試験地の年損失量が二瀬橋流域の年 損失量より大きくなることとを合わせ考えると、流域面積が大きくなると年損失量が小さくなると考えられ る。

また、当防災科学技術研究所の両試験地の年損失量は、年降水量の増加と共に増大する傾向がある。一方、 森林理水試験地の結果によると年損失量は、年降水量に関係なく一定である。この両者の年降水量と年損失 量の関係が異なる原因については確定し難い。 


\section{5。結語}

中国の淮河流域扔よび我が国の試験流域等の年水収支について解析を行った。その結果、我が国の河川流 域に抒いては、年流出率は $0.5 \sim 0.7$ 程度と大きく、一方、中国の淮河流域の年流出率は、0.2 0.5と比較的 小さい值を示した。

また、我が国の河川流域の年損失量については、浦白川流出試験地及び筑波学園流出試験地に比較してそ れょり流域面積の大きい二瀬橋流域の方が小さくなる。さらにそれょり流域面積の大きい関東地方の諸河川 の方が二瀬橋流域より年損失量が小さい傾向がある。これらの結果から年損失量は、流域面積の増大と共に 小さくなる傾向があるといえる。中国の淮河流域に関しては年損失量と流域面積の関係については、灌溉用 水等の人工的な水使用の定量的データが無いので今後の検討を必要としている。

さらに、浦白川流出試験地及び二瀬橋流域における年損失量と年降水量との関係を解析した結果では、 年降水量 $1,000 \mathrm{~mm}$ で年損失量 $450 \mathrm{~mm} 、 1,500 \mathrm{~mm}$ で $800 \mathrm{~mm}$ と年降水量の増加と共に年損失量が大きくなる。

謝 辞

浦白川流出試験地の水文観測に、常々御協力頂いている千葉県市原市公園みどり課、筑波研究学園流出試 験地の水位観測所の利用に便宜を計って頂いている土浦市外 15 町村土地改良区の方々および水文観測・討議 ・図面作成等に種々協力のあった当研究所の佐藤照子、中根和郎および大倉 博の各氏に感謝します。

参 考 文 献

1）岸井德雄：浦白川流出試験地の洪水流出特性.国立防災科学技術センター研究報告第20号，17-30,1978.

2) 岸井德雄 (1982)：浦白川流出試験地の洪水流出特性(その 2). 国立防災科学技術センター研究報告第29 号, 93-101, 1982.

3）岸井徳雄·中根和郎·大倉 博 ·佐藤照子 - 小西達男 : 筑波研究学園流出試験地の流出特性（第 2 報）. 国立防災科学技術センター研究報告第33号, 23-68, 1984 .

4) 岸井徳雄・佐藤照子・中根和郎 · 大倉 博 (1988): 浦白川流出試験地及び筑波研究学園流出試験地の水 収支の比較。国立防災科学技術センター研究報告第 40 号, 1-20,1988.

5) 木下武雄 (1982): 浦白川流出試験地における流出係数・流出率の変化. 国立防災科学技術センター研究 報告第27号，13-24, 1982 .

6）岸井德雄・曹 述互: 中国淮河の水収支について. 水文・水資源学会1994年研究発表会要旨集, 320 $321,1994$.

7）建設省・土木研究所：利水計画に打ける流況把握の研究. 第20回建設省技術研究発表会. 1966. 